\title{
Antioxidant activity of Agaricus sp. mushrooms by chemical, biochemical and electrochemical assays
}

\author{
Lillian Barros $^{\text {a }}$, Soraia Falcão ${ }^{\mathrm{a}, \mathrm{b}}$, Paula Baptista ${ }^{\mathrm{a}}$, Cristina Freire ${ }^{\mathrm{b}}$, Miguel Vilas-Boas ${ }^{\mathrm{a}}$, Isabel C.F.R. Ferreira ${ }^{\mathrm{a}, *}$ \\ a CIMO - Escola Superior Agrária, Instituto Politécnico de Bragança, Campus de Sta. Apolónia, Apartado 1172, $5301-855$ Bragança, Portugal \\ ${ }^{\mathrm{b}}$ REQUIMTE/Departamento de Química, Faculdade de Ciências, Universidade do Porto, Rua do Campo Alegre, 4169-007 Porto, Portugal
}

\section{A R T I C L E I N F O}

\section{Article history:}

Received 6 November 2007

Received in revised form 6 January 2008

Accepted 11 March 2008

\section{Keywords:}

Agaricus sp. mushrooms

Electrochemical assays

Lipid peroxidation inhibition

\begin{abstract}
A B S T R A C T
The antioxidant activity of five Agaricus sp. mushrooms was screened through chemical, biochemical and electrochemical techniques. The chemical assays allowed an evaluation of their reducing power and radical scavenging activity, while biochemical assays evaluated the lipid peroxidation inhibition capacity, using erythrocytes and brain cells as models; the electrochemical characterization of the mushrooms extracts were performed by cyclic voltammetry and differential pulse voltammetry. All the species proved to have antioxidant activity and particularly, by the electrochemical techniques, it has been shown that mushroom extracts revealed similar electrochemical responses, suggesting similar electroactive chemical composition, and oxidation potentials more positive than those of the standards (ascorbic and gallic acids). Agaricus silvaticus was the most efficient species presenting the lowest $\mathrm{EC}_{50}$ values in the chemical and biochemical assays, and the highest "antioxidant power" in the electrochemical assays.
\end{abstract}

(C) 2008 Elsevier Ltd. All rights reserved.

\section{Introduction}

Living cells, including those of man, animals, and plants, are continuously exposed to a variety of challenges that exert oxidative stress. Oxidative stress arises in a biological system after an increased exposure to oxidants, a decrease in the antioxidant capacity of the system, or both. It is often associated with or leads to the generation of reactive oxygen species (ROS), including free radicals, which are strongly implicated in the pathophysiology of diseases, such as cancer, rheumatoid arthritis, cirrhosis and arteriosclerosis as well as in degenerative processes associated with ageing. Reactive free radicals may come from endogenous sources through normal physiological and metabolic processes such as mitochondrial respiration. Alternatively, they could result from exogenous sources such as exposure to pollutants and ionizing irradiation, and particularly oxygen derived radicals are capable of oxidizing biomolecules, resulting in cell death and tissue damage (Ames, Shigenaga, \& Hagen, 1993; Chevion, Roberts, \& Chevion, 2000; Halliwell \& Gutteridge, 2003). Oxidation is also one of the most important processes of food deterioration since it may affect food safety, colour, flavour and texture.

Cells are equipped with several defence systems against free radical damage, including oxidative enzymes such as superoxide dismutase (SOD) and catalase (CAT), or chemical compounds such as $\alpha$-tocopherol, ascorbic acid, carotenoids, polyphenol compounds and glutathione (Niki, Shimaski, \& Mino, 1994). However, antioxi-

\footnotetext{
* Corresponding author. Tel.: +351 273303219; fax: +351 273325405

E-mail address: iferreira@ipb.pt (I.C.F.R. Ferreira).
}

dant supplements or antioxidant-containing foods may be used to help the human body to reduce oxidative damage or to protect food quality by preventing oxidative deterioration (Elmastasa, Isildaka, Turkekulb, \& Temura, 2007; Halliwell \& Gutteridge, 2003). In recent years, the restriction in the use of synthetic antioxidants, such as BHA (2-tert-butyl-4-methoxyphenol) and BHT (2,6-ditert-butyl-4-methylphenol), has caused an increased interest towards natural antioxidant substances (Ames, 1983; Branen, 1975). Natural antioxidants are being extensively studied for their capacity to protect organisms and cells from damage brought on by oxidative stress, the latter being considered a cause of ageing and degenerative diseases. The antioxidants contained in foods, especially vegetables, are phenolic compounds (phenolic acids and flavonoids), carotenoids, tocopherol and ascorbic acid (Cazzi et al., 1997; Elmastasa et al., 2007) that are important protective agents for human health (Block, Patterson, \& Subar, 1992; Gillman et al., 1995).

Mushrooms are rich sources of those compounds (Barros, Ferreira, Queirós, Ferreira, \& Baptista, 2007; Barros \& Calhelha et al., 2007; Valentão \& Andrade et al., 2005; Valentão \& Lopes et al., 2005) and in the last years we have reported several protocols to determine their antioxidant activity based on spectrophotometric techniques (Barros, Baptista, Correia, Morais, \& Ferreira, 2007; Barros, Baptista, \& Ferreira, 2007; Ferreira, Baptista, Vilas-Boas, \& Barros, 2007). Progressively, electrochemical techniques have been tested and developed as an alternative tool, for the evaluation of different food extracts, expressed in terms of "antioxidant power", due to their quickness, simplicity and low cost (Blasco, González, \& Escarpa, 2004; Blasco, Rogerio, González, \& Escarpa, 2005; Chevion, 
et al., 2000; Cosio, Buratti, Mannino, \& Benedetti, 2006; Korotkova, Karbainov, \& Shevchuk, 2002).

Antioxidant compounds can act as reduction agents and, in solutions, they tend to be easily oxidised at inert electrodes. Based on this fact, some of the previous cited authors established an interesting relationship between electrochemical behaviour of the antioxidant compounds and their resultant "antioxidant power", where "low oxidation potential" corresponds to "high antioxidant power". On the other hand, ascorbic acid and phenols compounds are common antioxidants in mushrooms. Electrochemical measurement at positive potentials will then correspond to the oxidation of "total phenolic" and ascorbic acid, plus all compounds with natural antioxidant properties and electrochemical activity, which are present in foods. Blasco et al. defined an "Electrochemical Index" to express the evaluation of the "total natural antioxidants (Blasco et al., 2004).

In the present work, cyclic voltammetry and differential pulse voltammetry were used to evaluate Agaricus sp. mushrooms antioxidant activity. Moreover, the lipid peroxidation inhibition capacity of the edible mushrooms was accessed by biochemical assays used as models for the lipid peroxidation damage in biomembranes, namely inhibition of $\beta$-carotene bleaching in the presence of linoleic acid radicals, inhibition of erythrocytes hemolysis mediated by peroxyl radicals, and inhibition of thiobarbituric acid reactive substances (TBARS) formation in brain cells. Their antioxidant properties were also evaluated through the reducing power determination and radical scavenging activity of 2,2-diphenyl-1-picrylhydrazyl (DPPH) radicals. Bioactive compounds such as phenols, flavonoids, ascorbic acid, $\beta$-carotene and lycopene were also determined.

\section{Materials and methods}

\subsection{Samples}

Five mushrooms species: Agaricus bisporus (Lange) Imbach, Agaricus arvensis Schaeffer, Agaricus romagnesii Wasser, Agaricus sivaticus Schaeff., and Agaricus silvicola (Vittadini) Peck were analysed. The first was a commercial sample obtained in a local supermarket. All the others were wild species and were collected in Bragança (Northeast of Portugal), in autumn 2006, under live pine trees (Pinus sp.) for the first two species and under oak trees (Quercus pyrenaica Willd.) for the last species. Taxonomic identification was made according to several authors (Courtecuisse \& Duhem, 1995; Moser, 1983) and representative voucher specimens were deposited at the herbarium of Escola Superior Agrária of Instituto Politécnico de Bragança. After collection and taxonomic identification, all the mushrooms were dried in a freeze-drier (Ly-8-FM-ULE, Snijders, HOLLAND) before analysis.

\subsection{Sample preparation}

The samples (typically $3 \mathrm{~g}$ ) were extracted by stirring with $100 \mathrm{ml}$ of methanol at $25^{\circ} \mathrm{C}$ at $150 \mathrm{rpm}$ for $24 \mathrm{~h}$ and filtered through Whatman No. 4 paper. The residue was then extracted with two additional $100 \mathrm{ml}$ portions of methanol. The combined methanolic extracts were evaporated at $40{ }^{\circ} \mathrm{C}$ to dryness and redissolved in methanol at a concentration of $100 \mathrm{mg} / \mathrm{ml}$, and stored at $4{ }^{\circ} \mathrm{C}$ for further use.

\subsection{Standards and reagents}

Standards BHA (2-tert-butyl-4-methoxyphenol), TBHQ (tertbutylhydroquinone), L-ascorbic acid, $\alpha$-tocopherol, gallic acid and (+)-catechin were purchased from Sigma (St. Louis, MO, USA). 2,2-diphenyl-1-picrylhydrazyl (DPPH) was obtained from Alfa Aesar (Ward Hill, MA, USA). Sodium perchlorate monohydrate, puriss grade, was purchased from Fluka, and kept at $30^{\circ} \mathrm{C}$ before use. All other chemicals were obtained from Sigma Chemical Co. (St. Louis, MO, USA). Methanol was obtained from Pronalab (Lisbon, Portugal). Water was treated in a Mili-Q water purification system (TGI Pure Water Systems, USA).

\subsection{Chemical assays}

\subsubsection{Determination of bioactive components}

Bioactive compounds in the mushrooms extracts were determined by colorimetric assays, based on procedures described by us in previous works (Barros \& Baptista et al., 2007; Barros \& Ferreira et al., 2007).

For phenolic compounds estimation, the extract solution $(1 \mathrm{ml})$ was mixed with of Folin and Ciocalteu's phenol reagent $(1 \mathrm{ml})$. After $3 \mathrm{~min}$, saturated sodium carbonate solution $(1 \mathrm{ml}$ ) was added to the mixture and adjusted to $10 \mathrm{ml}$ with distilled water. The reaction was kept in the dark for 90 min, after which the absorbance was read at $\lambda=725 \mathrm{~nm}$ (Analytikijena 200-2004 spectrophotometer). Gallic acid was used to calculate the standard curve (0.01$0.4 \mathrm{mM} ; \quad Y=2.8557 \mathrm{X}-0.0021 ; R^{2}=0.9999$ ) and the results were expressed as $\mathrm{mg}$ of gallic acid equivalents (GAEs) per $\mathrm{g}$ of extract.

For flavonoid contents determination, the mushroom extract $(250 \mu \mathrm{l})$ was mixed with distilled water $(1.25 \mathrm{ml})$ and $\mathrm{NaNO}_{2}$ solution $(5 \%, 75 \mu \mathrm{l})$. After $5 \mathrm{~min}, \mathrm{AlCl}_{3} \cdot \mathrm{H}_{2} \mathrm{O}$ solution $(10 \%, 150 \mu \mathrm{l})$ was added. After $6 \mathrm{~min}, \mathrm{NaOH}(1 \mathrm{M}, 500 \mu \mathrm{l})$ and distilled water $(275 \mu \mathrm{l})$ were added to the mixture. The solution was mixed well and the intensity of pink colour was measured at $\lambda=510 \mathrm{~nm}$. (+)-catechin was used to calculate the standard curve $(0.022-0.34 \mathrm{mM}$; $\left.Y=0.9629 \mathrm{X}-0.0002 ; R^{2}=0.9999\right)$ and the results were expressed as $\mathrm{mg}$ of $(+)$-catechin equivalents (CEs) per $\mathrm{g}$ of extract.

For ascorbic acid determination, the dried methanolic extract $(100 \mathrm{mg})$ was re-extracted with metaphosphoric acid $(1 \%, 10 \mathrm{ml})$ for $45 \mathrm{~min}$ at room temperature and filtered through Whatman No. 4 filter paper. The filtrate $(1 \mathrm{ml})$ was mixed with 2,6-dichlorophenolindophenol $(9 \mathrm{ml})$ and the absorbance was measured within $30 \mathrm{~min}$ at $515 \mathrm{~nm}$ against a blank. Content of ascorbic acid was calculated on the basis of the calibration curve of authentic L-ascorbic acid $\left(0.020-0.12 \mathrm{mg} / \mathrm{ml} ; Y=3.4127 \mathrm{X}-0.0072 ; R^{2}=0.9905\right)$ and the results were expressed as $\mathrm{mg}$ of ascorbic acid/g of extract.

For $\beta$-carotene and lycopene determination, the dried methanolic extract $(100 \mathrm{mg})$ was vigorously shaken with acetone-hexane mixture $(4: 6,10 \mathrm{ml})$ for $1 \mathrm{~min}$ and filtered through Whatman No. 4 filter paper. The absorbance of the filtrate was measured at $\lambda=453,505$ and $663 \mathrm{~nm}$. Contents of $\beta$-carotene and lycopene were calculated according to the following equations: lycopene $(\mathrm{mg} / 100 \mathrm{ml})=-0.0458 \mathrm{~A} 663+0.372$ A505 -0.0806 A453; $\beta$-carotene $(\mathrm{mg} / 100 \mathrm{ml})=0.216 \mathrm{~A} 663-0.304 \mathrm{~A} 505+0.452 \mathrm{~A} 453$. The results were expressed as $\mu$ g of carotenoid/g of extract.

\subsubsection{DPPH radical scavenging activity}

Various concentrations of mushroom extracts $(0.3 \mathrm{ml})$ were mixed with methanolic solution containing DPPH radicals $\left(6 \times 10^{-5} \mathrm{mM}, 2.7 \mathrm{ml}\right)$. The mixture was shaken vigorously and left to stand for $60 \mathrm{~min}$ in the dark (until stable absorption values were obtained). The reduction of the DPPH radical was determined by measuring the absorption at $\lambda=517 \mathrm{~nm}$. The radical scavenging activity (RSA) was calculated as a percentage of DPPH discolouration using the equation: \% $\mathrm{RSA}=\left[\left(A_{\mathrm{DPPH}}-A_{\mathrm{S}}\right) / A_{\mathrm{DPPH}}\right] \times 100$, where $A_{S}$ is the absorbance of the solution when the sample extract has been added at a particular level, and $A_{\mathrm{DPPH}}$ is the absorbance of the DPPH solution. The extract concentration providing $50 \%$ of radicals scavenging activity $\left(\mathrm{EC}_{50}\right)$ was calculated from the graph of 
RSA percentage against extract concentration. BHA and $\alpha$-tocopherol were used as standards (Barros \& Baptista et al., 2007; Barros \& Ferreira et al., 2007).

\subsubsection{Reducing power}

Various concentrations of mushroom methanolic extracts $(2.5 \mathrm{ml})$ were mixed with sodium phosphate buffer $(\mathrm{pH} 6.6$, $200 \mathrm{mM}, 2.5 \mathrm{ml}$ ) and potassium ferricyanide (1\% w/v, $2.5 \mathrm{ml})$. The mixture was incubated at $50{ }^{\circ} \mathrm{C}$ for $20 \mathrm{~min}$. Trichloroacetic acid $(10 \%, 2.5 \mathrm{ml})$ was added, and the mixture was centrifuged at $1000 \mathrm{rpm}$ for $8 \mathrm{~min}$ (Centorion K24OR-2003 refrigerated centrifuge). The upper layer $(5 \mathrm{ml})$ was mixed with deionised water $(5 \mathrm{ml})$ and ferric chloride $(0.1 \%, 1 \mathrm{ml})$, and the absorbance was measured spectrophotometrically at $700 \mathrm{~nm}$. The extract concentration providing 0.5 of absorbance $\left(\mathrm{EC}_{50}\right)$ was calculated from the graph of absorbance at $\lambda=700 \mathrm{~nm}$ against extract concentration. BHA and $\alpha$-tocopherol were used as standards (Barros \& Baptista et al., 2007; Barros \& Ferreira et al., 2007).

\subsection{Biochemical assays}

\subsubsection{Inhibition of $\beta$-carotene bleaching}

The antioxidant activity of mushroom extracts was evaluated by the $\beta$-carotene linoleate model system. A solution of $\beta$-carotene was prepared by dissolving $\beta$-carotene $(2 \mathrm{mg})$ in chloroform $(10 \mathrm{ml})$. Two millilitres of this solution were pipetted into a $100 \mathrm{ml}$ round-bottom flask. After the chloroform was removed at $40{ }^{\circ} \mathrm{C}$ under vacuum, linoleic acid $(40 \mathrm{mg})$, Tween 80 emulsifier $(400 \mathrm{mg})$, and distilled water $(100 \mathrm{ml})$ were added to the flask with vigorous shaking. Aliquots $(4.8 \mathrm{ml})$ of this emulsion were transferred into different test tubes containing different concentrations of the mushroom extracts $(0.2 \mathrm{ml})$. The tubes were shaken and incubated at $50^{\circ} \mathrm{C}$ in a water bath. As soon as the emulsion was added to each tube, the zero time absorbance was measured at $\lambda=470 \mathrm{~nm}$ using a spectrophotometer. Absorbance readings were then recorded at 20-min intervals until the control sample had changed colour. A blank, devoid of $\beta$-carotene, was prepared for background subtraction. Lipid peroxidation (LPO) inhibition was calculated using the following equation: LPO inhibition $=(\beta-$ carotene content after $2 \mathrm{~h}$ of assay/initial $\beta$-carotene content) $\times 100$. The extract concentration providing $50 \%$ antioxidant activity $\left(\mathrm{EC}_{50}\right)$ was calculated from the graph of antioxidant activity percentage against extract concentration. TBHQ was used as standard (Barros \& Baptista et al., 2007; Barros \& Ferreira et al., 2007).

\subsubsection{Inhibition of erythrocyte hemolysis mediated by peroxyl free radicals}

The antioxidant activity of the mushroom extracts was measured as the inhibition of erythrocyte hemolysis. Blood was obtained from a male ram (churra galega transmontana) of body weight $\sim 67 \mathrm{~kg}$. Erythrocytes separated from the plasma and the buffy coat were washed three times with phosphate buffer saline (PBS, $10 \mathrm{mM}, 10 \mathrm{ml}$ ) at pH 7.4 (prepared by mixing $10 \mathrm{mM}$ of $\mathrm{NaH}_{2} \mathrm{PO}_{4}$ and $\mathrm{Na}_{2} \mathrm{HPO}_{4}$, and $125 \mathrm{mM}$ of $\mathrm{NaCl}$ in 11 of distilled water) and centrifuged at $1500 \mathrm{~g}$ for $5 \mathrm{~min}$. During the last washing, the erythrocytes were obtained by centrifugation at $1500 \mathrm{~g}$ for $10 \mathrm{~min}$. A suspension of erythrocytes in PBS $(20 \%, 0.1 \mathrm{ml})$ was added to 2,2'-azobis(2-amidinopropane)dihydrochloride (AAPH, $200 \mathrm{mM}, 0.2 \mathrm{ml}$ ) solution (in PBS) and mushroom methanolic extracts of different concentrations $(0.1 \mathrm{ml})$. The reaction mixture was shaken gently $(30 \mathrm{rpm})$ while being incubated at $37^{\circ} \mathrm{C}$ for $3 \mathrm{~h}$. The reaction mixture was diluted with PBS $(8 \mathrm{ml})$ and centrifuged at $3000 \mathrm{~g}$ for $10 \mathrm{~min}$; the absorbance of its supernatant was then read at $\lambda=540 \mathrm{~nm}$ by a spectrophotometer, after filtration with a syringe filter (cellulose membrane $30 \mathrm{~mm}$,
$0.20 \mu \mathrm{m}$, Titan). The percentage hemolysis inhibition was calculated by the equation\% hemolysis inhibition $=\left[\left(A_{\mathrm{AAPH}}-A_{\mathrm{S}}\right)\right]$ $\left.A_{\mathrm{AAPH}}\right] \times 100$, where $A_{\mathrm{S}}$ is the absorbance of the sample containing the mushroom extract, and $A_{\mathrm{AAPH}}$ is the absorbance of the control sample containing no mushroom extract. The extract concentration providing $50 \%$ inhibition $\left(\mathrm{EC}_{50}\right.$ ) was calculated from the graph of hemolysis inhibition percentage against extract concentration. L-Ascorbic acid was used as standard (Barros \& Baptista et al., 2007; Barros \& Ferreira et al., 2007).

\subsubsection{Inhibition of lipid peroxidation using thiobarbituric acid reactive substances (TBARS)}

Brains were obtained from pig (Sus scrofa) of body weight $\sim 150$ $\mathrm{kg}$, dissected and homogenized with a Polytron in ice-cold Tris- $\mathrm{HCl}$ buffer ( $\mathrm{pH} 7.4,20 \mathrm{mM})$ to produce a 1:2 (w/v) brain tissue homogenate which was centrifuged at $3000 \mathrm{~g}$ for $10 \mathrm{~min}$. An aliquot $(0.1 \mathrm{ml})$ of the supernatant was incubated with the mushrooms extracts $(0.2 \mathrm{ml})$ in the presence of $\mathrm{FeSO}_{4}(10 \mu \mathrm{M} ; 0.1 \mathrm{ml})$ and ascorbic acid $(0.1 \mathrm{mM} ; 0.1 \mathrm{ml})$ at $37^{\circ} \mathrm{C}$ for $1 \mathrm{~h}$. The reaction was stopped by the addition of trichloroacetic acid $(28 \% \mathrm{w} / \mathrm{v}, 0.5 \mathrm{ml})$, followed by thiobarbituric acid (TBA, $2 \%, 0.38 \mathrm{ml}$ ), and the mixture was then heated at $80^{\circ} \mathrm{C}$ for $20 \mathrm{~min}$. After centrifugation at $3000 \mathrm{~g}$ for $10 \mathrm{~min}$ to remove the precipitated protein, the colour intensity of the malondialdehyde (MDA)-TBA complex in the supernatant was measured by its absorbance at $\lambda=532 \mathrm{~nm}$. The inhibition ratio (\%) was calculated using the following formula: Inhibition ratio $(\%)=[(A-B) / A] \times 100 \%$, where $A$ and $B$ were the absorbance of the control and the compound solution, respectively. The extract concentration providing $50 \%$ lipid peroxidation inhibition $\left(\mathrm{EC}_{50}\right)$ was calculated from the graph of antioxidant activity percentage against extract concentration. BHA was used as standard (Barros \& Baptista et al., 2007; Barros \& Ferreira et al., 2007).

\subsection{Electrochemical characterization}

\subsubsection{Instrumentation}

Cyclic voltammetry (CV) and differential pulse voltammetry (DPV) measurements were performed on an Autolab PGSTAT 302 potentiostat/galvanostat using a closed standard three electrode cell. A glassy carbon (BAS, $\phi=0.314 \mathrm{~cm}^{2}$ ) was used as the working electrode and a Pt foil as the counter electrode. All potentials are refer to an $\mathrm{Ag} / \mathrm{AgCl} 3 \mathrm{M} \mathrm{KCl}$ reference electrode (Methrom). Prior to use, the working electrode was polished in an aqueous suspension of $0.3 \mu \mathrm{m}$ alumina (Beuhler) on a Master-Tex (Beuhler) polishing pad, then rinsed with water. Subsequently, in a chemical treatment, the electrode was sonicated in $6 \mathrm{M} \mathrm{HCl}$ for $1 \mathrm{~min}$, and then in methanol. This cleaning procedure was applied always before any electrochemical measurements.

\subsubsection{Procedure}

All the mushroom extracts and standard compounds were studied in methanol/acetate buffer $0.1 \mathrm{M}(\mathrm{pH} 4) / \mathrm{NaClO}_{4}$ (70:28:2) solutions. For calibration standards (ascorbic and gallic acids), the concentration was set between 0.1 and $1 \mathrm{mM}$, while for mushroom extracts solutions the concentration was changed between 0.5 and $15 \mathrm{mg} / \mathrm{ml}$. All solutions were analysed immediately after preparation and the electrochemical responses recorded after the glassy carbon electrode immersion, to minimize adsorption of species onto the electrode surface prior to the run.

Cyclic voltammetry was used to characterization the electrochemical responses between 0 and $1.2 \mathrm{~V}$, at $0.1 \mathrm{~V} \mathrm{~s}^{-1}$, whereas the antioxidant power was evaluated by DPV, using the following operating conditions for DPV were set at $60 \mathrm{mV}$ pulse amplitude and $0.030 \mathrm{~V} \mathrm{~s}^{-1}$ as scan rate. For each extract, the current density was plotted as a function of mushroom extract mass and compared with those of the standards. 


\subsection{Statistical analysis}

For each one of the Agaricus sp. three samples were analysed and also all the assays were carried out in triplicate. The results are expressed as mean values and standard error (SE) or standard deviation (SD). The mushrooms antioxidant activity was analysed using one-way analysis of variance (ANOVA) followed by Tukey's HSD Test with $\alpha=0.05$. This treatment was carried out using SAS v. 9.1.3 program.

\section{Results and discussion}

\subsection{Evaluation of antioxidant properties by chemical and biochemical assays}

Several chemical and biochemical assays were used to screen the antioxidant properties: reducing power (measuring the conversion of a $\mathrm{Fe}^{3+} /$ ferricyanide complex to the ferrous form), scavenging activity on DPPH radicals (measuring the decrease in DPPH radical absorption after exposure to radical scavengers), inhibition of $\beta$-carotene bleaching (by neutralizing the linoleatefree radical and other free radicals formed in the system which attack the highly unsaturated $\beta$-carotene models), and inhibition of lipid peroxidation in brain tissue (measured by the colour intensity of MDA-TBA complex). The assays were performed in the whole extract, since it could be more beneficial than isolated constituents; a bioactive individual component can change its properties in the presence of other compounds present in the extracts. According to Liu (2003), additive and synergistic effects of phytochemicals in fruits and vegetables are responsible for their potent bioactive properties and the benefit of a diet rich in fruits and vegetables is attributed to the complex mixture of phytochemicals present in whole foods. This explains why no single antioxidant can replace the combination of natural phytochemicals to achieve health benefits.

Table 1 shows $\mathrm{EC}_{50}$ values obtained in the antioxidant activity assays of Agaricus sp. mushrooms. All the species proved to have antioxidant activity, namely radical scavenging activity and lipid peroxidation inhibition capacity. The antioxidant activity was better (lower $\mathrm{EC}_{50}$ values) in chemical assays than in the biochemical assay using animal cells.

Table 2 presents phenol, flavonoid, ascorbic acid and carotenoids concentrations contained in the five Agaricus sp. mushroom extracts. Phenols were the major antioxidant components found in the extracts, followed by flavonoids $(3.88-1.65 \mathrm{mg} / \mathrm{g})$. Ascorbic acid was found in small amounts $(0.02-0.04 \mathrm{mg} / \mathrm{g})$, and $\beta$-carotene and lycopene were only found in vestigial amounts $(<9 \mu \mathrm{g} / \mathrm{g})$, which is in agreement with previous reports concerning ascorbic acid and $\beta$-carotene quantification in other mushroom species (Barros \& Ferreira et al., 2007). Agaricus silvaticus revealed a higher content in phenol and flavonoid compounds, which significantly $(p<0.05)$ decreased in the other species. In fact, A. silvaticus was the most efficient species (lower $\mathrm{EC}_{50}$ values) concerning antioxidant activity, while $A$. arvensis presented lower antioxidant properties (higher $\mathrm{EC}_{50}$ values) which are compatible to its lower phenols content. Some authors have already reported a direct correlation between mushrooms antioxidant activity and total phenolic content, although the antioxidant action is raised by other substances such as tocopherols and $\beta$-carotene (Cheung, Cheung, \& Ooi, 2003). The bioactivity of phenolics may be related to their ability to chelate metals, inhibit lipoxygenase and scavenge free radicals (Decker, 1997). Also, in food systems, flavonoids can act as free radical scavengers and terminate the radical chain reactions that occur during the oxidation of triglycerides. Therefore, they present antioxidative efficiency in oils, fats and emulsions (Roedig-Penman \& Gordon, 1998).

\subsection{Evaluation of antioxidant properties by electrochemical techniques}

Fig. 1a and b shows the cyclic voltamograms of the standards ascorbic and gallic acids, respectively. Both compounds present typical irreversible oxidation processes, as observed in many antioxidant substances (Cosio et al., 2006; Gunckel et al., 1998; Kilmartin, Zou, \& Waterhouse, 2001), with one anodic peak at $E_{\mathrm{pa}}=0.26 \mathrm{~V}$ for ascorbic and two anodic peaks at $E(\mathrm{I})_{\mathrm{pa}}=0.36 \mathrm{~V}$, $E(\mathrm{II})_{\mathrm{pa}}=0.62 \mathrm{~V}$ for gallic acid. The same irreversible electrochemical behaviour was observed for all Agaricus sp. extracts (Fig. 1c), although with oxidation potentials more positive than the standards, around $0.9 \mathrm{~V}$. These results showed that both standards are oxidised at less positive potentials than the compounds responsible for the electrochemical responses of the mushrooms extracts, and indicate that, under the electrochemical conditions used, neither of the standards are present in the mushroom extracts. The similarity in the oxidation potential between all the Agaricus species studied (Table 3) indicates that the different extracts should have an analogous composition in respect to the electroactive species.

Table 1

$\mathrm{EC}_{50}$ values (mean $\pm \mathrm{SD}$ ) obtained in the antioxidant activity assays of Agaricus sp. In each column different letters mean significant differences $(p<0.05$ )

\begin{tabular}{|c|c|c|c|c|c|}
\hline & \multicolumn{5}{|c|}{ Antioxidant properties $\left(\mathrm{EC}_{50}\right.$ values; $\mathrm{mg} / \mathrm{ml}$ ) } \\
\hline & DPPH scavenging activity & Reducing power & $\beta$-Carotene bleaching inhibition & Hemolysis inhibition & TBARS inhibition \\
\hline A. arvensis & $15.85 \pm 0.27 a$ & $4.20 \pm 0.04 a$ & $48.30 \pm 0.83 a$ & $>50 a$ & $>50 a$ \\
\hline A. bisporus & $9.61 \pm 0.07 b$ & $3.63 \pm 0.02 b$ & $21.39 \pm 0.45 b$ & $>50 a$ & $46.82 \pm 0.03 b$ \\
\hline A. romagnesii & $6.22 \pm 0.10 c$ & $2.23 \pm 0.01 d$ & $4.36 \pm 0.86 d$ & $35.38 \pm 0.9 c$ & $22.38 \pm 0.05 d$ \\
\hline A. silvaticus & $5.37 \pm 0.06 \mathrm{~d}$ & $2.08 \pm 0.05 \mathrm{e}$ & $3.72 \pm 0.21 d$ & $22.15 \pm 0.31 d$ & $17.79 \pm 0.10 \mathrm{e}$ \\
\hline A. silvicola & $6.39 \pm 0.16 c$ & $3.24 \pm 0.01 c$ & $14.75 \pm 1.57 c$ & $43.75 \pm 0.11 b$ & $31.97 \pm 0.04 c$ \\
\hline
\end{tabular}

Table 2

Bioactive compounds (mean \pm SD) obtained for Agaricus sp. In each column different letters mean significant differences $(p<0.05)$

\begin{tabular}{|c|c|c|c|c|c|}
\hline Sample & Total phenols (mg/g) & Flavonoids (mg/g) & Ascorbic acid (mg/g) & $\beta$-Carotene $(\mu \mathrm{g} / \mathrm{g})$ & Lycopene $(\mu \mathrm{g} / \mathrm{g})$ \\
\hline A. arvensis & $2.72 \pm 0.17 d$ & $1.65 \pm 0.09 d$ & $0.02 \pm 0.00 c$ & $8.52 \pm 0.38 a$ & $4.70 \pm 0.25 a$ \\
\hline A. bisporus & $4.49 \pm 0.16 c$ & $1.73 \pm 0.11 d$ & $0.03 \pm 0.01 b$ & $1.95 \pm 0.10 \mathrm{~d}$ & $0.91 \pm 0.06 \mathrm{~d}$ \\
\hline A. romagnesii & $6.18 \pm 0.44 b$ & $2.87 \pm 0.12 c$ & $0.04 \pm 0.00 \mathrm{a}$ & $1.32 \pm 0.03 e$ & $0.38 \pm 0.02 \mathrm{e}$ \\
\hline A. silvaticus & $8.95 \pm 0.30 a$ & $3.88 \pm 0.04 a$ & $0.04 \pm 0.00 a$ & $5.42 \pm 0.10 \mathrm{~b}$ & $2.63 \pm 0.06 b$ \\
\hline A. silvicola & $6.40 \pm 0.17 b$ & $3.40 \pm 0.01 b$ & $0.04 \pm 0.00 a$ & $3.02 \pm 0.12 c$ & $1.14 \pm 0.08 c$ \\
\hline
\end{tabular}




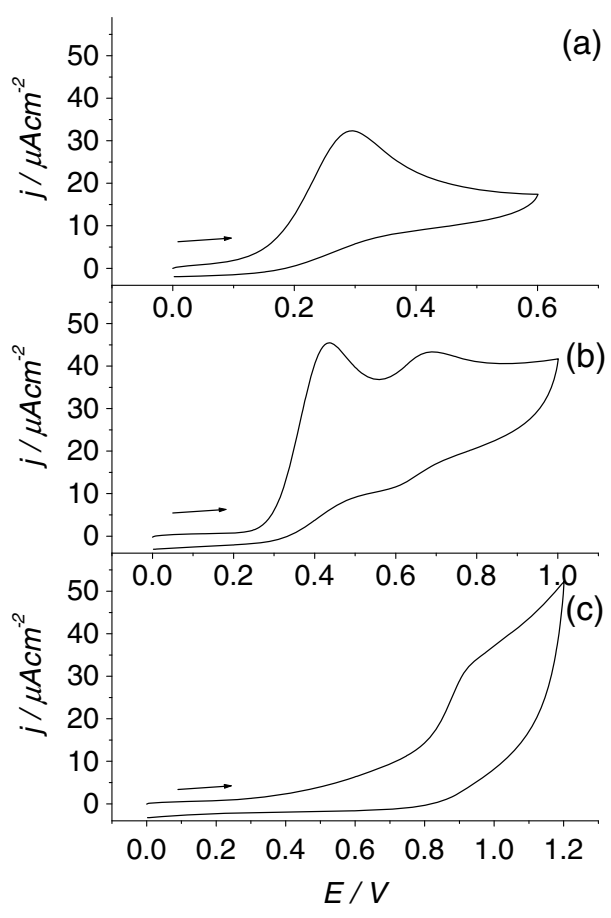

Fig. 1. Cyclic voltamogram, at $0.1 \mathrm{~V} \mathrm{~s}^{-1}$, of methanol/acetate buffer $0.1 \mathrm{M}(\mathrm{pH} 4)$ / $\mathrm{NaClO}_{4}$ (70:28:2) solutions of: (a) $0.5 \mathrm{mM}$ ascorbic acid, (b) $0.5 \mathrm{mM}$ gallic acid, (c) $5 \mathrm{mg} / \mathrm{ml}$ extract of $A$. silvaticus.

Table 3

Electrochemical results from cyclic voltammetry and differential pulse voltammetry of the methanolic mushroom extracts

\begin{tabular}{lllll}
\hline Sample & $E_{1 / 2} / \mathrm{V}$ & $\begin{array}{l}\text { Slope } / \mu \mathrm{A} \mathrm{cm} \\
\mathrm{mg}^{-1} \mathrm{ml}\end{array}$ & $\begin{array}{l}\text { A.P. (AA) } \\
\mathrm{mg} / \mathrm{g}\end{array}$ & $\begin{array}{l}\text { A.P. (GA) } \\
\mathrm{mg} / \mathrm{g}\end{array}$ \\
\hline A. arvensis & 0.90 & 0.55 & 3.1 & 2.7 \\
A. bisporus & 0.92 & 0.79 & 1.9 & 1.6 \\
A. romagnesii & 0.92 & 0.50 & 2.8 & 2.4 \\
A. silvaticus & 0.92 & 0.85 & 4.4 & 3.7 \\
A. silvicola & 0.94 & 0.85 & 4.6 & 4.0 \\
Ascorbic acid & 0.26 & 204.75 & 1000 & 616 \\
Gallic acid & $0.36 / 0.62$ & 247.81 & 1302 & 1000 \\
\hline
\end{tabular}

A.P. - antioxidant power; AA - ascorbic acid; GA - gallic acid.

Cyclic voltammetry is frequently used for the characterization of electroactive systems. However, when organic substances are present, there are greater chances for adsorption phenomena on the electrode surface, limiting the use of this technique to quantitative measurements. To overcome this constriction and gain quantitative information in the antioxidant capabilities of the extracts, differential pulse voltammetry was used. In this technique the current is measured before and after the potential pulse application allowing the discrimination of effects, like absorption on the electrode, that are approximately constants in a certain potential interval (Brett \& Brett, 1993).

Fig. 2 shows the differential pulse voltamograms for the mushroom extracts. They resemble the behaviour of the cyclic voltamogram responses, with one peak at the same potential values. The exception is A. bisporus extract where it is possible to observe a broad peak around $0.6 \mathrm{~V}$. In fact, with this technique the peaks are better resolved than in $\mathrm{CV}$, overcoming the difficulties in accessing a correct baseline.

The differential pulse voltamograms, at several concentrations of gallic acid, are shown in Fig. 3. As can be seen there is an increase in peak current with the increase in gallic acid concentration,

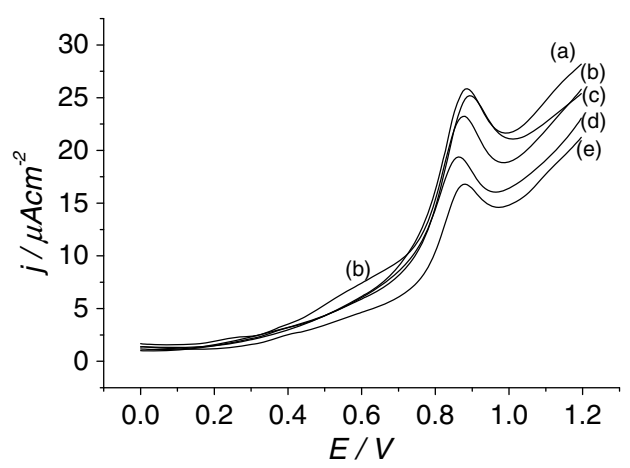

Fig. 2. Differential pulse voltamogram of $10 \mathrm{mg} / \mathrm{ml}$ Agaricus methanolic extracts in methanol/acetate buffer $0.1 \mathrm{M}(\mathrm{pH} 4) / \mathrm{NaClO}_{4}$ (70:28:2) solutions. (a) A. silvicola, (b) A. bisporus, (c) A. silvaticus, (d) A. arvensis, and (e) A. romagnesii.

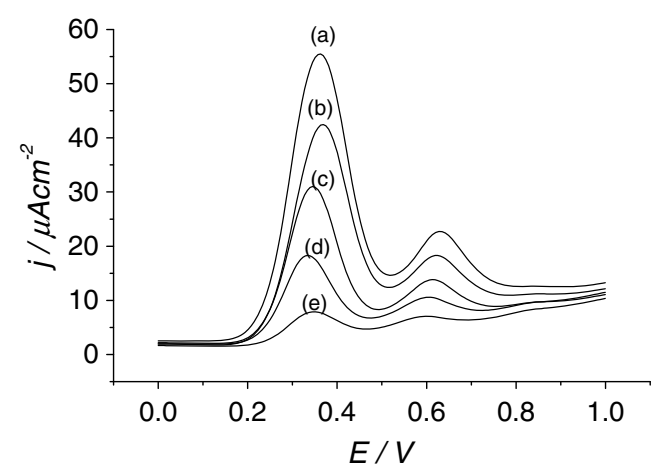

Fig. 3. Differential pulse voltamograms of gallic acid in methanol/acetate buffer $0.1 \mathrm{M}(\mathrm{pH} 4) / \mathrm{NaClO}_{4}$ (70:28:2) solutions. (a) $0.20 \mathrm{mg} / \mathrm{ml}$, (b) $0.15 \mathrm{mg} / \mathrm{ml}$, (c) $0.1 \mathrm{mg} /$ $\mathrm{ml}$, (d) $0.05 \mathrm{mg} / \mathrm{ml}$, and (e) $0.02 \mathrm{mg} / \mathrm{ml}$.

which leads to a linear relation between the two parameters. The same behaviour was found for ascorbic acid and mushroom extracts (Fig. 4 and Table 3 ) although the slopes for the plots peak current density vs. extract concentration are very different. For this technique the peak current density, $j$, depends, not only on the concentration, but also on the electron transfer kinetics and the diffusion coefficient of the electroactive species (or the average of several species) (Brett \& Brett, 1993), preventing the direct comparison between the standards and samples data. Moreover, the standards tested were not detected within the mushrooms extracts, at an electrochemically detectable concentration, and

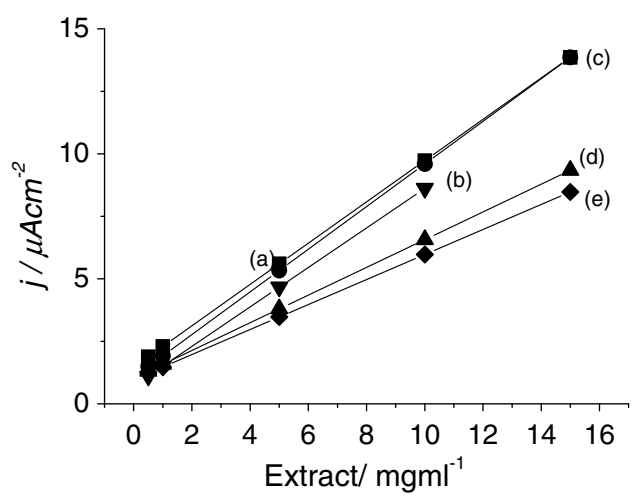

Fig. 4. Variation of the peak current density, in DPV voltamograms, with extract concentration. (a) A. silvicola, (b) A. bisporus, (c) A. silvaticus, (d) A. arvensis, and (e) A. romagnesii. 
therefore the relation between current density and concentration for the mushroom extracts will differs from that of gallic and ascorbic acid. The difference between the slopes of the two standards in Table 3, reflects the difference between their diffusion coefficients. However, when compared with the extracts slopes, the enormous discrepancy cannot be explained on the basis of their different diffusion coefficients (species belong to a chemically comparable family of phenol compounds), but to the amount of effective electroactive mass in the mushroom extract composition. Based on the similarity in the cyclic voltamograms of Agaricus sp, it can be assumed that the species responsible for the electrochemical activity are chemically similar as well as their diffusion coefficient. In this context and based on the slopes values of peak current density vs. extract concentration plots, it can be concluded that the amount of electroactive phenolic compounds in A. bisporus, $A$. silvaticus and $A$. silvicola are almost double of that present in the extract of $A$. arvensis and $A$. romagnesii.

In order to express the "antioxidant power" of the mushrooms extracts in equivalent terms we compared the results with that of the standards. We must mention that at very low and high concentrations of extract there are significant deviations in linearity of $j$ vs. mass, most probably due to adsorption phenomena on the electrode. The values are presented in Table 3, and are expressed in terms of either gallic or ascorbic acid. These results show that A. silvicola and A. silvaticus exhibit the highest "antioxidant power" in agreement with the results obtained in the biochemical assays. The values obtained from the electrochemical experiment are lower than those resulting from Folin Ciocalteús assay. This outcome is frequently observed when comparing the colorimetric method with others and is attributed to the overestimation of the "total polyphenolic" content due to the interferences of other non-phenolic species like reduction sugars (Blasco et al., 2005).

Overall, all the species proved to have antioxidant properties, namely radical scavenging activity and lipid peroxidation inhibition capacity. By using electrochemical techniques, it was also proved that mushroom extracts have a similar composition on the electroactive species, which exhibit oxidation potentials more positive than the standards. A. silvaticus was the most efficient species presenting the lowest $\mathrm{EC}_{50}$ values in the chemical and biochemical assays, and the highest "antioxidant power" in the electrochemical assays. Finally, the work described in this study showed that cyclic voltammetry and differential pulse voltammetry can be considered as important techniques for the evaluation of mushrooms antioxidant properties.

\section{Acknowledgements}

The authors are grateful to Fundação para a Ciência e a Tecnologia (FCT-Portugal) for financial support through the Project Ref. PPCDT/AGR/56661/2004.

\section{References}

Ames, B. M. (1983). Dietary carcinogens and anticarcinogens: Oxygen radical and degenerative disease. Science, 221, 1256-1263.

Ames, B. M., Shigenaga, M. K., \& Hagen, T. M. (1993). Oxidants, antioxidants and the degenerative diseases of aging. Proceedings of the National Academy Sciences, 90, 7915-7922.

Barros, L., Baptista, P., Correia, D. M., Morais, J. S., \& Ferreira, I. C. F. R. (2007). Effects of conservation treatment and cooking on the chemical composition and antioxidant activity of Portuguese wild edible mushrooms. Journal of Agricultural and Food Chemistry, 55, 4781-4788.

Barros, L., Baptista, P., \& Ferreira, I. C. F. R. (2007). Effect of Lactarius piperatus fruiting body maturity stage on antioxidant activity measured by several biochemical assays. Food and Chemical Toxicology, 45, 1731-1737.

Barros, L., Calhelha, R. C., Vaz, J. A., Ferreira, I. C. F. R., Baptista, P., \& Estevinho, L. M. (2007). Antimicrobial activity and bioactive compounds of Portuguese wild edible mushrooms. European Food Research and Technology, 225, 151-156.

Barros, L., Ferreira, M.-J., Queirós, B., Ferreira, I. C. F. R., \& Baptista, P. (2007). Total phenols, ascorbic acid, â-carotene and lycopene in Portuguese wild edible mushrooms and their antioxidant activities. Food Chemistry, 103, 314-419.

Blasco, A. J., González, M. C., \& Escarpa, A. (2004). Electrochemical approach for discriminating and measuring predominant flavonoids and phenolic acids using differential pulse voltammetry: Towards an electrochemical index of natural antioxidants. Analytical Chimica Acta, 511, 71-81.

Blasco, A. J., Rogerio, M. C., González, M. C., \& Escarpa, A. (2005). "Electrochemical Index" as a screening method to determine "total polyphenolics" in foods: A proposal. Analytical Chimica Acta, 539, 237-244.

Block, G., Patterson, B., \& Subar, A. (1992). Fruits, vegetables and cancer prevention: A review of the epidemiological evidence. Nutrition and Cancer - An International Journal, 18, 1-29.

Branen, A. L. (1975). Toxicology and biochemistry of butylated hydroxy anisole and butylated hydroxy toluene. Journal of the American Oil Chemists Society, 52, 59-63.

Brett, C. M. A., \& Brett, A. M. O. (1993). Electrochemistry - principles methods and applications. Oxford: Oxford University Press. p. 219.

Cazzi, R., Ricardy, R., Aglitti, T., Gatta, V., Petricone, P., \& De Salvia, R. (1997) Ascorbic acid and b-carotene as modulators of oxidative damage. Carcinogenesis, 18, 223-228.

Cheung, L. M., Cheung, P. C. K., \& Ooi, V. E. C. (2003). Antioxidant activity and total phenolics of edible mushroom extracts. Food Chemistry, 81, 249-255.

Chevion, S., Roberts, M. A., \& Chevion, M. (2000). The use of cyclic voltammetry for the evaluation of antioxidant capacity. Free Radical Biology and Medicine, 28, 860-870.

Cosio, M. S., Buratti, S., Mannino, S., \& Benedetti, S. (2006). Use of an electrochemical method to evaluate the antioxidant activity of herb extracts from the Labiatae family. Food Chemistry, 97, 725-731.

Courtecuisse, R., \& Duhem, B. (1995). In Mushrooms and toadstools of Britain and Europe. London: HarperCollins Publishers.

Decker, E. A. (1997). Phenolics: Prooxidants or antioxidants? Nutrition Reviews, 55, 396-407.

Elmastasa, M., Isildaka, O., Turkekulb, I., \& Temura, N. (2007). Determination of antioxidant activity and antioxidant compounds in wild edible mushrooms. Journal of Food Composition and Analysis, 20, 337-345.

Ferreira, I. C. F. R., Baptista, P., Vilas-Boas, M., \& Barros, L. (2007). Free-radical scavenging capacity and reducing power of wild edible mushrooms from northeast Portugal. Food Chemistry, 100, 1511-1516.

Gillman, M. W., Cupples, A., Gagnon, D., Posner, B. M., Ellison, R. C., Castelli, W. P., et al. (1995). Protective effect of fruits and vegetables on development of stroke in men. Journal of the American Medical Association, 273, 1113-1117.

Gunckel, S., Santander, P., Cordano, G., Ferreira, J., Munoz, S., Nunez-Vergara, L. J. et al. (1998). Antioxidant activity of gallates: An electrochemical study in aqueous media. Chemico-Biological Interactions, 114, 45-59.

Halliwell, B., \& Gutteridge, J. M. C. (2003). Free radicals in biology and medicine. Oxford, UK: Oxford University Press.

Kilmartin, P. A., Zou, H., \& Waterhouse, A. L. (2001). A cyclic voltammetry method suitable for characterizing antioxidant properties of wine and wine phenolics. Journal of Agricultural and Food Chemistry, 49, 1957-1965.

Korotkova, E. I., Karbainov, Y. A., \& Shevchuk, A. V. (2002). Study of antioxidant properties by voltammetry. Journal of Electroanalytical Chemistry, 518, 56-60.

Liu, R. H. (2003). Health benefits of fruits and vegetables are from additive and synergistic combination of phytochemicals. American Journal of Clinical Nutrition, 78, 517S-520S.

Moser, M. (1983). In keys to Agaricus and Boleti (Polyporales, Boletales, Agaricales, Russulales). London: Roger Phillips.

Niki, E., Shimaski, H., \& Mino, M. (1994). Antioxidantism - free radical and biological defence. Tokyo: Gakkai Syuppan Center.

Roedig-Penman, A., \& Gordon, M. H. (1998). Antioxidant properties of myricetin and quercetin in oil and emulsions. Journal of the American Oil Chemists Society, 75, $169-180$

Valentão, P., Andrade, P. B., Rangel, J., Ribeiro, B., Silva, B. M., Baptista, P., et al (2005). Effect of the conservation procedure on the contents of phenolic compounds and organic acids in Chanterelle (Cantharellus cibarius) mushroom. Journal of Agricultural and Food Chemistry, 53, 4925-4931.

Valentão, P., Lopes, G., Valente, M., Barbosa, P., Andrade, P. B., Silva, B. M., et al. (2005). Quantification of nine organic acids in wild mushrooms. Journal of Agricultural and Food Chemistry, 53, 3626-3630. 